\title{
Detection of ade $A B C$ efllux pump encoding genes and antimicrobial effect of Mentha longifolia and Menthol on MICs of imipenem and ciprofloxacin in clinical isolates of Acinetobacter baumannii
}

\author{
Hassan Mahmoudi ${ }^{1 \dagger}$, Leili Shokoohizadeh ${ }^{1 \dagger}$, Nayreh Zare Fahim ${ }^{1}$, Ali Mohamadi Bardebari ${ }^{1}$, \\ Shirin Moradkhani ${ }^{2}$ and Mohammad Yousef Alikhani ${ }^{1,3^{*}}$
}

\begin{abstract}
Background: Acinetobacter baumannii is an opportunistic pathogen that causes nosocomial infections especially in patients in intensive care units (ICUs). Accordingly, the aim of our study was to detection of adeABC efllux pump encoding genes and antimicrobial effect of the essential oil of Mentha longifolia and Menthol on the minimum inhibitory concentration (MIC) of imipenem and ciprofloxacin in clinical isolates of A. baumannii.

Methods: A total of 75 clinical isolates of $A$. baumannii were collected. The presence of efflux pump genes was detected by polymerase chain reaction (PCR). The minimum inhibitory concentration (MIC) of the essential oil of Mentha longifolia and Menthol and their combined effect with antibiotics were measured by microbroth dilution method and fractional inhibitory concentration (FIC) index.
\end{abstract}

Results: The frequency of adeA, adeB, and adeC genes in clinical isolates of A. baumannii were 86.7, 90.7, and 92\%, respectively. When the essential oil of Mentha longifolia was combined with ciprofloxacin and imipenem, MICs decreased 4- and 8-fold, respectively. In the combination of menthol with imipenem, the resistance to imipenem was reduced from 0 - to 16 -fold in $90 \%(63 / 70)$ of the isolates.

Conclusion: The presence of efflux pump genes in more than $90 \%$ of $A$. baumannii isolates indicates its potential role in inducing imipenem- and ciprofloxacin-resistance in this bacterium. Menthol has an antimicrobial effect as an active ingredient in Mentha longifolia. In the future, the combination of medicinal plants with antibiotics can be used as a complement in treating diseases caused by drug-resistant bacteria such as A. baumannii infections.

Keywords: Acinetobacter baumannii, Efflux pump, Menthol, Mentha longifolia

\footnotetext{
* Correspondence: alikhani43@yahoo.com; alikhani@umsha.ac.ir

† Hassan Mahmoudi and Leili Shokoohizadeh contributed equally to this work.

'Department of Microbiology, Faculty of Medicine, Medical Microbiology, Hamadan University of Medical Sciences, Hamadan, Iran

${ }^{3}$ Brucellosis Research Center, Hamadan University of Medical Sciences, Hamadan, Iran

Full list of author information is available at the end of the article
}

(c) The Author(s). 2020 Open Access This article is licensed under a Creative Commons Attribution 4.0 International License, which permits use, sharing, adaptation, distribution and reproduction in any medium or format, as long as you give appropriate credit to the original author(s) and the source, provide a link to the Creative Commons licence, and indicate if changes were made. The images or other third party material in this article are included in the article's Creative Commons licence, unless indicated otherwise in a credit line to the material. If material is not included in the article's Creative Commons licence and your intended use is not permitted by statutory regulation or exceeds the permitted use, you will need to obtain permission directly from the copyright holder. To view a copy of this licence, visit http://creativecommons.org/licenses/by/4.0/ The Creative Commons Public Domain Dedication waiver (http://creativecommons.org/publicdomain/zero/1.0/) applies to the data made available in this article, unless otherwise stated in a credit line to the data. 


\section{Background}

Acinetobacter baumannii is known as one of the most important hospital pathogens. Controlling the infections caused by this bacterium has created many problems due to its multiple drug resistance. Therefore, antibiotic treatment has become a challenge for hospitalized patients, especially in intensive care units (ICUs) [1]. Efflux pumps are considered as one of the most important mechanisms of intrinsic and acquired antibiotic resistance in bacteria that can remove toxic substances such as antibiotics, drugs, and chemicals, as well as secretion of cellular products out of the cell. Efflux pumps prevent proper concentrations of toxic substances used to inhibit bacteria and, as a defence mechanism against harmful substances in the environment, allow bacteria to survive in different environments. Different antibiotics serve as substrates for different pumps. Efflux pumps are one of the intrinsic and acquired resistance pathways in bacteria that can cause resistance to a wide range of antibiotics and disinfectants. Mutations in the efflux genes are associated with their expression and consequently with increased antibiotic resistance [2,3]. The AdeABC pump is one of the most important systems of the efflux family which belongs to the RND family and adeA, adeB, and ade $C$ genes encode it. AdeA is a membrane fusion protein, AdeB is a multi-drug transporter, and $\mathrm{AdeC}$ is an outer membrane protein [1]. Many chemicals can enhance the expression of ade $A B C$ genes and results in resistance to aminoglycoside, fluoroquinolones, betalactams, chloramphenicol, and tetracycline antibiotics. Various inhibitors have been used to deactivate efflux pumps including Phenylalanine-Arginine Beta-Naphthylamide (PA $\mathrm{NN})$, Naphthyl-methylpiperazine, and CarbonylChlorophenyl Hydrazou which by affecting and controlling the AdeABC pump can prevent antibiotics from being expelled from bacteria. Thus, antibiotics reach the minimum inhibitory concentration (MIC) [4]. Because of the toxicity of most of these compounds in humans, their widespread use is prohibited. Hence, the new challenge is to find nontoxic compounds or compounds with less toxicity [4]. As a result, the elimination of chemical inhibitors and the use of natural inhibitors such as plant compounds have recently attracted much attention. One of the medicinal plants that have shown antimicrobial properties is Mentha longifolia. Mentha longifolia is a member of the Laminacea family which is a perennial herb. It consists of more than 25 species and grows wildly in humid regions of central and southern Europe, Southwestern Asia, the Mediterranean, and North Africa. The essential oil of the Mentha longifolia species has shown an antimicrobial activity (comparable to available antibiotics) against a range of microorganisms including bacteria, fungi, and protozoa [5]. Essential oils and their constituents have significant hydrophobic properties which cause materials to penetrate into the cell membranes of bacteria and mitochondria disrupting their structure and creating more permeability. This causes the leakage of ions and other contents from the cell [6]. So far, there has been no study about the inhibitory effects of Mentha longifolia on efflux pumps in A. baumannii. Due to the frequency and availability of this plant as well as its therapeutic usages, the aim of this study was to investigate the effect of natural herbal inhibitors such as Mentha longifolia on MICs of ciprofloxacin and imipenem in clinical isolates of $A$. baumannii with adeABC efflux pumps encoding genes isolated from hospitalized patients in ICU wards.

\section{Methods}

\section{Bacterial strain}

A total of 75 clinical isolates of $A$. baumannii were isolated from clinical samples of patients hospitalized in ICUs from January to August 2018. Seventy imipenem- and ciprofloxacin-resistant isolates were selected for the study.

\section{Antimicrobial susceptibility}

The antibiotic susceptibility of A. baumannii to ciprofloxacin $(5 \mu \mathrm{g})$ and imipenem $(10 \mu \mathrm{g})$ was detected by disk diffusion and microbroth dilution methods according to clinical \& laboratory standards institute (CLSI) criteria [7, 8]. Pseudomonas aeruginosa ATCC 27853 and Escherichia coli ATCC 25922 were used as control strains for antibiotic susceptibility testing.

\section{Detection of adeABC genes}

The bacterial genomic DNAs were extracted from overnight cultures of $A$. baumannii isolates using a commercial DNA purification kit (Sinaclon Co, Tehran, Iran) according to the manufacturer's protocol. All isolates were screened for the presence of efflux pump-encoded genes including adeA, adeB, ade $C$ using a multiplex PCR technique. The sequences of primers [9] used in the present study have been shown in Table 1.

The PCR mix was prepared in the final volume of $25 \mu \mathrm{l}$ containing $1 \mu \mathrm{l}(10 \mathrm{pmol})$ of each primer, $2 \mu \mathrm{l}$ template DNA, $12.5 \mu \mathrm{l}$ PCR Master Mix, and distilled water. DNA amplification was conducted in a thermal cycler $\left(\mathrm{S} 1000^{\mathrm{m}}\right.$, Bio-Rad, Hercules, CA, USA), under the following conditions: initial denaturation at $94^{\circ} \mathrm{C}$ for $5 \mathrm{~min}$,

Table 1 The primers used in this study for detection of adeABC genes

\begin{tabular}{lllcc}
\hline Gene & Primer sequence $\left(5^{\prime} \mathbf{3}^{\prime}\right.$ ) & Amplicon size(bp) & Reference \\
\hline ade A & $\mathbf{F}$ & ATCTTCCTGCACGTGTACAT & $\mathbf{5 1 3}$ & 9 \\
& $\mathbf{R}$ & GGCGTTCATACTCACTAACC & & \\
ade B & $\mathbf{F}$ & TTAACGATAGCGTTGTAACC & $\mathbf{5 4 1}$ & 9 \\
& $\mathbf{R}$ & TGAGCAGACAATGGAATAGT & & \\
ade C & $\mathbf{F}$ & TACGGACTGCTACGCTTAAT & $\mathbf{5 2 7}$ & 9 \\
& $\mathbf{R}$ & AACAGGATGACCTGCTAACA & & \\
\hline
\end{tabular}


followed by 30 cycles of denaturation at $94{ }^{\circ} \mathrm{C}$ for $30 \mathrm{~s}$, annealing temperature of $55^{\circ} \mathrm{C}$ for $1 \mathrm{~min}$, extension at $72{ }^{\circ} \mathrm{C}$ for $1 \mathrm{~min}$, followed by a final extension at $72^{\circ} \mathrm{C}$ for $6 \mathrm{~min}$. The electrophoresis of the amplified DNA fragments, along with a $100 \mathrm{bp}$ DNA ladder, was performed using agarose gel $1.5 \%$. The size of the amplification fragment for ade $A$, ade $B$ and $a d e C$ genes were 513, 541 and $527 \mathrm{bp}$, respectively.

\section{Preparation of the essential oil of Mentha longifolia}

For this experimental study, the medicinal plant Mentha longifolia was collected from Alvand Mountains of Hamadan in the west of Iran, was identified in the School of Pharmacy of Hamadan University of Medical Sciences, and was assigned a herbarium code (herbarium code 37). The essential oil was obtained by hydrodistillation of air-dried leaves using a Clevenger-type apparatus for $3 \mathrm{~h}$. Finally, the essential oil was obtained as a light yellow liquid. The obtained essential oil was dried over anhydrous sodium sulfate and, after filtration, stored in dark vials at $4{ }^{\circ} \mathrm{C}$.

\section{Preparation of menthol solution}

Menthol (ALDRICH, Lot BCBQ32755V) was purchased as powder from Sigma Aldrich Company. One $\mu \mathrm{g}$ of menthol was dissolved in $1 \mathrm{ml}$ distilled water (as the solvent).

\section{Antibacterial activities of menthol and essential oil of Mentha longifolia}

The essential oil of Mentha longifolia and Menthol with the final concentrations of $512 \mu \mathrm{g} / \mathrm{ml}$ were loaded on blank disks and their antibacterial activities against the clinical isolates of $A$. baumannii were investigated by the disk diffusion method. The diameter of blank disk was 6 $\mathrm{mm}$ and $50 \mu \mathrm{L}$ from each dilution of $M$. longifolia essential oil and Menthol were added to the blank disks. The bacterial suspension with a turbidity equivalent to 0.5 McFarland $\left(1.5 \times 10^{8} \mathrm{CFU} / \mathrm{ml}\right)$ in the Brain Heart Infusion broth (BHI) (Merck, Germany) was prepared and cultured on a Muller-Hinton Agar (Merck, Germany) plate. The disk containing dimethyl sulfoxide (DMSO) was used as a solvent of essential oil and as the negative control. The plates were incubated at $37^{\circ} \mathrm{C}$ for $24 \mathrm{~h}$ [10]. Finally, the antibacterial activity of the essential oil was evaluated by observing the inhibitory zones around the disks. The MICs of the essential oil Mentha longifolia, Menthol, imipenem and ciprofloxacin were determined by the broth microdilution method. According to CLSI guidelines the MICs of resistance to imipenem and ciprofloxacin in Acinetobacter isolates is $\geq 16 \mu \mathrm{g} / \mathrm{ml}$ and $\geq$ $4 \mu \mathrm{g} / \mathrm{ml}$, respectively [8]. The tests were repeated three times to achieve the required accuracy.

\section{Assessment of the synergistic effects}

The synergistic effects of Mentha longifolia essential oil and Menthol, imipenem, and ciprofloxacin were assessed using the microbroth dilution method. Serial dilutions from 512 to $0.25 \mu \mathrm{g} / \mathrm{ml}$ of each concentration were prepared in microtiter plates at the volume of $10 \mu \mathrm{l}$. Then, $90 \mu \mathrm{l}$ of the bacterial suspension in the Brain Heart Infusion broth (BHI) media (Merck, Germany) was added to the microtiter plate to produce a final inoculum of $5 \times 10^{5} \mathrm{CFU} / \mathrm{ml}$. The plates were incubated for $24 \mathrm{~h}$ at $37^{\circ} \mathrm{C}$. For combining two antimicrobial agents, fractional inhibitory concentration index (FICi) was calculated as follows: [(MIC of drug A in combination) / MIC of drug A alone $)]+[($ MIC of drug B in combination) / (MIC of drug B alone)]. The FICi index was interpreted as follows: Synergy $\leq 0.5$, Addition $>0.5$ to 1.0 , Indifference $1.0<$ to $<4.0$, and Antagonism $\geq 4.0$ [11].

\section{Statistical analysis}

This investigation was a descriptive-application study. SPSS software V 21 was used for the statistical analyses. The $P$ value and confidence intervals were less than 0.05 and $95 \%$, respectively.

\section{Results}

\section{Antimicrobial susceptibility testing}

The antibiogram results showed that 72 (97\%) and 70 (94\%) isolates of A. baumannii were resistant to ciprofloxacin and imipenem, respectively. According to the results of disk diffusion method, the antibacterial effects of menthol and the essential oil of Mentha longifolia were observed in the inhibition zones around disks (Fig. 1).

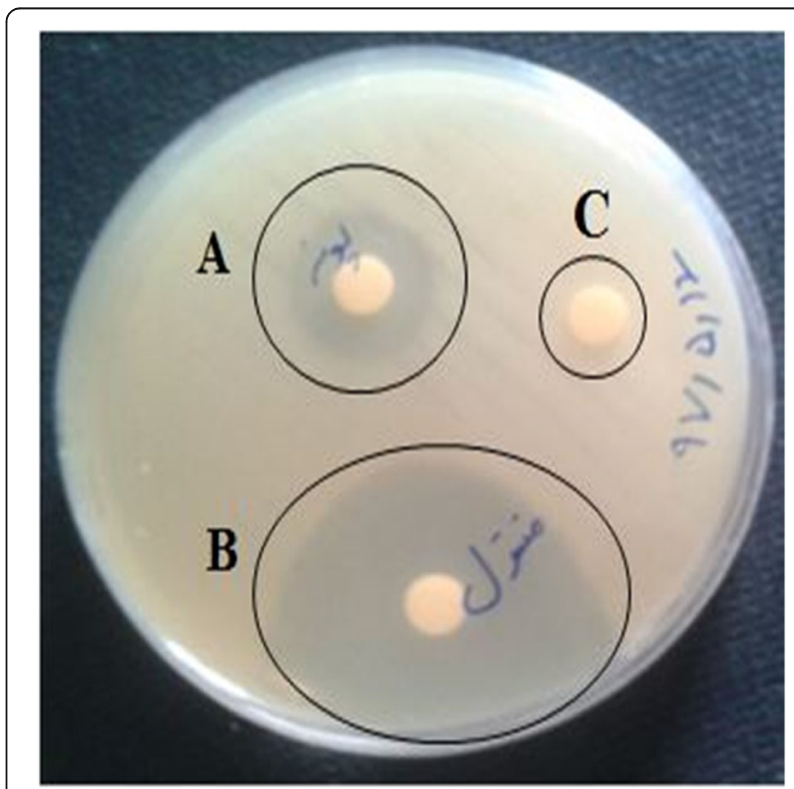

Fig. 1 Inhibitory effect of Mentha longifolia essential oil and Menthol with the final concentrations of $512 \mu \mathrm{g} / \mathrm{ml}$ on A. baumannii isolate. a: Mentha longifolia; b: Menthol; c: Negative Control (DMSO) 


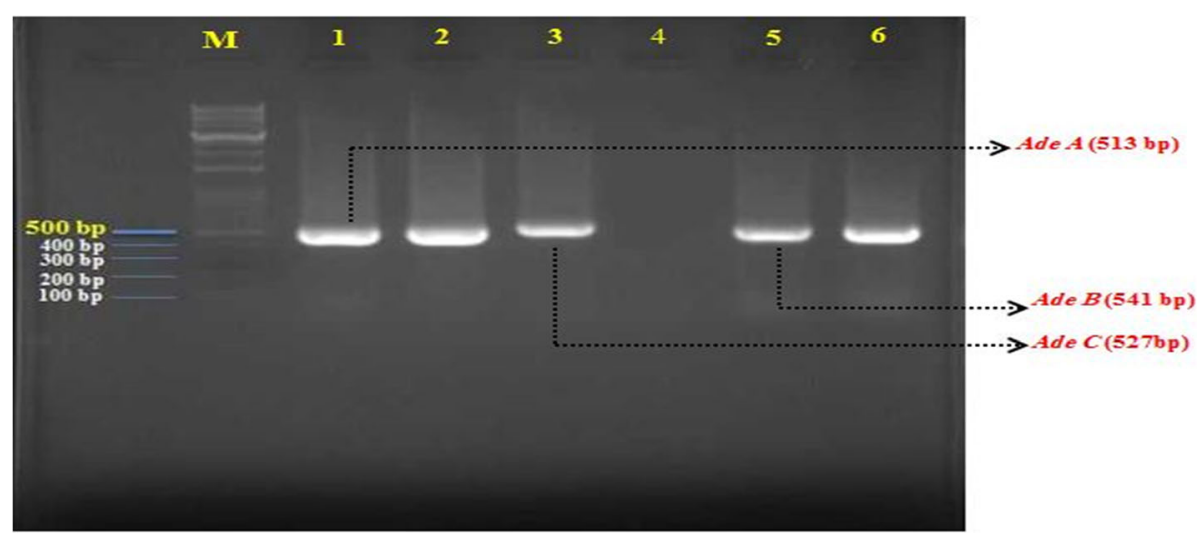

Fig. 2 Gel electrophoresis of the efflux pupm adeABC genes of A. baumannii isolates. M: 100 bp DNA marker; Lane 1-2: adeA; Lane 3: adeB; Lane 4: Negative control. Lane 5-6: adeC

\section{Frequency of adeABC efflux pump genes}

The multiplex PCR was successfully performed and 513 bp, $541 \mathrm{bp}$, and $527 \mathrm{bp}$ bands were amplified as adeA, $a d e B$, and $a d e C$ genes, respectively. The results showed that the frequencies of $a d e A, a d e B$, and $a d e C$ genes were 65(86.7\%), 68(90.7\%), and 69(92\%), respectively (Fig. 2). The combination of these genes among the A. baumannii isolates included as ade $A+a d e B$ 62(82.7\%), ade $A+$ ade $C$ 64(85.3\%), adeB + adeC 67(89.3\%), and ade $A+$ ade $B+$ adeC $62(82.7 \%)$. These results showed that the drug efflux systems are associated with resistance to ciprofloxacin and imipenem in clinical isolates of $A$. baumannii. These results showed that the drug efflux systems are associated with resistance to ciprofloxacin and imipenem in clinical isolates of A. baumannii.

\section{MIC and the synergistic effects of imipenem and} ciprofloxacin in combination with Mentha longifolia and Menthol

The result showed that the MICs of imipenem and ciprofloxacin against clinical isolates of $A$. baumannii were between 8 and $128 \mu \mathrm{g} / \mathrm{ml}$ and $4-32 \mu \mathrm{g} / \mathrm{ml}$, respectively (Tables 2,3). The checkerboard method was used to assess synergism by calculating the $\mathrm{FICi}$, which is an interaction coefficient that indicates whether the combined inhibitory/bacteriostatic effects of drugs are synergistic, additive, or indifferent. The means of FICi for all isolates in relation to Mentha longifolia-ciprofloxacin, Menthol-ciprofloxacin, Mentha longifolia-imipenem, and Menthol-imipenem were calculated as 3.5, $1.23,0.40$, and 1.23 , respectively (Tables 2,3 ). The FICi results suggest that the combined effect of imipenemmenthol and imipenem-Mentha longifolia against $A$. baumannii isolates is synergistic. The effects of the efflux pump inhibitors were determined by detecting a 4fold or greater increase in susceptibility (reduction in the MICs) after incorporation of Mentha longifolia and Menthol. Totally, in the combination of antibiotics with Mentha longifolia and Menthol, the MICs for 25 out of 70 isolates $(35.71 \%)$ were decreased significantly 4- to 32-fold. When the essential oil of Mentha longifolia was combined with ciprofloxacin and imipenem, MICs decreased 4- and 8-fold, respectively. In the combination of Menthol with imipenem, in 90\% (63/70) of the isolates the resistance to imipenem was reduced from 0 - to 16 -fold.

\section{Discussion}

In recent years, $A$. baumannii strains with multiple drug resistance patterns (MDR), extensive drug resistance (XDR), and pan drug resistance (PDR) have been increasing causing many problems for the treatment of

Table 2 MICs and FICi of imipenem, Mentha longifolia and Menthol against A. baumannii

\begin{tabular}{|c|c|c|c|c|c|c|c|}
\hline $\begin{array}{l}\text { A. baumannii isolates } \\
\text { No }(\%)\end{array}$ & MIC IMP $(\mu \mathrm{g} / \mathrm{ml})$ & $\begin{array}{l}\text { MIC M. longifolia } \\
(\mu \mathrm{g} / \mathrm{ml})\end{array}$ & $\begin{array}{l}\text { MIC (IMP+ M. longifolia) } \\
(\mu \mathrm{g} / \mathrm{ml})\end{array}$ & $\mathrm{FICi}$ & $\begin{array}{l}\text { MIC Menthol } \\
(\mu \mathrm{g} / \mathrm{ml})\end{array}$ & $\begin{array}{l}\text { MIC (IMP+ Menthol) } \\
(\mu \mathrm{g} / \mathrm{ml})\end{array}$ & $\overline{\mathrm{FICi}}$ \\
\hline $5(7.15)$ & 8 & 2.5 & 0.5 & 0.26 & 4 & 0.25 & 0.09 \\
\hline $2(2.85)$ & 16 & 2.5 & 1 & 0.46 & 4 & 0.5 & 0.1 \\
\hline $35(50)$ & 32 & 2.5 & 2 & 0.86 & 4 & 1 & 0.28 \\
\hline $12(17.15)$ & 64 & 2.5 & 4 & 1.66 & 4 & 2 & 0.5 \\
\hline $16(22.85)$ & 128 & 2.5 & 8 & 3.26 & 4 & 4 & 1.03 \\
\hline
\end{tabular}

The MICs of imipenem and ciprofloxacin in resistant $A$. baumannii was $\geq 16(\mu \mathrm{g} / \mathrm{ml})$ and $\geq 4(\mu \mathrm{g} / \mathrm{ml})$, respectively 
Table 3 MICs and FICi of ciprofloxacin, M. longifolia and Menthol against A. baumannii

\begin{tabular}{|c|c|c|c|c|c|c|c|}
\hline $\begin{array}{l}\text { A. baumannii isolates } \\
\text { No }(\%)\end{array}$ & $\begin{array}{l}\text { MIC CIP } \\
(\mu \mathrm{g} / \mathrm{ml})\end{array}$ & $\begin{array}{l}\text { MIC } \boldsymbol{M} \text {. longifolia } \\
(\mu \mathrm{g} / \mathrm{ml})\end{array}$ & $\mathrm{MIC}(\mathrm{CIP}+$ M. longifolia) $(\mu \mathrm{g} / \mathrm{ml})$ & $\mathrm{FICi}$ & $\begin{array}{l}\text { MIC Menthol } \\
(\mu \mathrm{g} / \mathrm{ml})\end{array}$ & $\begin{array}{l}\text { MIC (CIP + Menthol }) \\
(\mu \mathrm{g} / \mathrm{ml})\end{array}$ & $\mathrm{FICi}$ \\
\hline $10(14.2)$ & 4 & 2.5 & 2 & 1.3 & 4 & 1 & 0.5 \\
\hline $17(24.6)$ & 8 & 2.5 & 4 & 2.1 & 4 & 2 & 0.75 \\
\hline $31(50)$ & 16 & 2.5 & 8 & 3.7 & 4 & 4 & 1. \\
\hline $12(17.4)$ & 32 & 2.5 & 16 & 6.9 & 4 & 8 & 2. \\
\hline
\end{tabular}

patients infected with A. baumannii isolates [12, 13]. According to the results of some researches from Iran and other countries, $31 \%$ of bacterial isolates from patients admitted to ICUs were identified as A. baumannii [14, 15]. Based on the results of our research, more than $90 \%$ of $A$. baumannii isolates showed resistance to ciprofloxacin and imipenem. A study has shown that the resistance of $A$. baumannii not only to beta-lactams and carbapenems but also to other families of antibiotics including aminoglycosides and fluoroquinolones has been increasing [16]. Ardebili et al. reported that more than $100 \%$ of the A. baumannii isolates were resistant to ciprofloxacin, with MICs ranging from 4 to $\geq 128 \mu \mathrm{g} / \mathrm{mL}$, however, the MIC values in the current study ranged from 4 to $32 \mu \mathrm{g} / \mathrm{ml}$ [17]. Resistance to ciprofloxacin is increasing in Iran and worldwide [18-20]. Nowak et al. showed that $97 \%$ of $A$. baumannii isolates which were previously cultured from respiratory tract samples from 15 hospitals in Greece, Italy, and Spain were resistant to imipenem [21]. Blitchtein et al. have also shown that 97.5\% of A. baumannii isolated from a hospital in Lima, Peru were carbapenem-resistant [22]. The resistance of clinical isolates of $A$. baumannii to imipenem is rapidly increasing in Iran. A meta-analysis in Iran revealed that $55 \%$ of $A$. baumannii isolates were resistant to imipenem and $74 \%$ showed MDR phenotypes [23]. The results of studies in our area indicate that resistance to imipenem and other antibiotics is increasing over the time. In 2008 , this rate was $16.3 \%$ but has reached $95 \%$ in the current study indicating that carbapenems are not a suitable choice for the treatment of $A$. baumannii infections [24]. Our findings highlight the critical need for a comprehensive monitoring and infection control policy as well as a national susceptibility review program that evaluates MDR A. baumannii isolates from different parts of Iran.

The results of our study were consistent with those of previous studies demonstrating the important role of efflux pumps in the resistance to ciprofloxacin. In our study, the frequencies of $a d e A, a d e B$, and $a d e C$ genes in clinical isolates of $A$. baumannii were 86.7, 90.7, and $92 \%$, respectively. In accordance with our results, Japooni et al. detected $a d e \mathrm{~A}, a d e B$, and $a d e C$ genes in 100,100 , and $96.5 \%$ of $A$. baumannii isolates, respectively. In the study of Khayat et al., adeA, adeB, and adeC genes were detected in $100 \%$ of $A$. baumannii strains in Iran $[18,19]$. Similar studies have also reported that the prevalence of these genes is from 53 to $97 \%$ [25-27]. In this study, the high frequency of ade $A B C$ genes in the $A$. baumannii isolates suggests that one of the mechanisms involved in creating a high resistance to ciprofloxacin and imipenem can be AdeABC efflux pumps. However, the expressions of genes coding for AdeABC efflux pumps were not assessed by the real-time PCR technique which is a limitation of the current study. It is relatively difficult both to determine if one or more efflux pumps have been inhibited and to identify the target efflux pump. A bacterium may possess many efflux pumps including several uncharacterized or even unidentified efflux pumps.

One of the main goals of this study was to investigate the effect of Mentha longifolia essential oil and menthol as natural efflux pump inhibitors compared with synthetic substances. Thus, using the essential oil of Mentha longifolia and menthol decreases the toxic risks of antibiotics [28]. Studies have shown that the essential oil of Mentha longifolia has antibacterial properties against Gram-positive and Gram-negative bacteria such as Listeria monocytogenes, Staphylococcus aureus, Escherichia coli, Shigella spp., Salmonella typhimurium, and Pseudomonas aerosinosa. It is also known that the essential oil of Mentha longifolia has a higher antimicrobial effect than its alcoholic extract due to the presence of menthol, menthone, pepogon, isomenthol. Menthol is the most important compound of Mentha longifolia with its antimicrobial effects reported in various studies [2932]. Combination therapy increases antimicrobial activity, minimizes antibiotic toxicity, prevents the occurrence of mutations involved in bacterial resistance during treatment, and also leads to a synergistic antimicrobial activity. In this study, the effect of synergism in the combination of menthol-imipenem and essential oil of Mentha longifolia with imipenem was greater than that of menthol-ciprofloxacin and essential oil of Mentha longifolia with ciprofloxacin. In addition, Mentholimipenem significantly reduced the MIC of imipenem (16-fold). Moreover, Mentha longifolia-ciprofloxacin and Mentha longifolia decreased the MICs of ciprofloxacin and imipenem 4- and 8-fold, respectively. Guclo et al. studied the effect of menthol on MDR A. baumannii 
and found that menthol has an antimicrobial effect [29]. Seasotiya et al. investigated the inhibitory effect of 35 different herbal extracts on efflux pumps and showed that these extracts increased the accumulation of drugs in bacteria and reduced the efflux of fluoroquinolones [33].

In our study, menthol and essential oil of Mentha longifolia reduced the MICs of imipenem and ciprofloxacin 4- to 8-fold, which are lower than the results of synthetic efflux pump inhibitors such as Carbonyl Cyanide 3-Chlorophenylhydrazone (CCCP). Ardebili et al. showed that the susceptibility of $A$. baumannii strains to ciprofloxacin highly increased in the presence of efflux pump inhibitors (EPI) and CCCP reduced the MICs 2to 64-fold [17]. Many compounds extracted from the plant were introduced as EPI which inhibited bacterial pathogens. These compounds affected different efflux pumps including: MexAB-OprM in Pseudomonas aeruginosa; Nor A in Staphylococcus aureus, Bacillus cereus, Staphylococcus epidermidis, and Salmonella enteritidis; ND in Escherichia coli and Food-borne pathogens; and $M s r A$ and Tet $K$ in S. epidermidis [34-42].

\section{Conclusions}

According to our results, the essential oil of Mentha longifolia and menthol as its main constituent can be good candidates to investigate antimicrobial activities and potential efflux pump inhibitors in A. baumannii. Thus, natural and synthetic derivatives of medicinal plants can be considered as potential adjuvants to maintain the efficacy of antibiotics in the treatment of infectious diseases. However, more research is needed regarding the molecular interactions between these compounds and potential efflux pumps.

\section{Abbreviations}

ICU: Intensive care units; PCR: Polymerase chain reaction; MIC: Minimum inhibitory concentration; FIC: Fractional inhibitory concentration; CLSI: Clinical \& laboratory standards institute; $\mathrm{BHI}$ : Brain heart infusion broth; DMSO: Dimethyl sulfoxide

\section{Acknowledgements}

This research has been supported by Vice Chancellor for Research \& Technology of Hamadan University of Medical Sciences, Hamadan, IRAN (Grant no: 9610266851).

\section{Authors' contributions}

MYA, LSHZ and HM designed the experiments and wrote the manuscript. $\mathrm{HM}$ and NZF conducted the experiment. LSHZ and AMB are analyzed the data. LSHZ, SHM and HM participated in the initial draft and the revision of the manuscript. MYA and HM revised the final version of the manuscript. All authors read and approved the final manuscript.

\section{Funding}

This research has been supported by Vice Chancellor for Research \& Technology of Hamadan University of Medical Sciences, Hamadan, IRAN (Grant no: 9610266851).

\section{Availability of data and materials}

The datasets used and analyzed in the current study are available from the corresponding author on reasonable request.

Ethics approval and consent to participate

Not applicable.

\section{Consent for publication}

Person identifiable data was not collected as part of this study and no individual level data are presented within this publication.

\section{Competing interests}

The authors declare that they have no competing interests.

\section{Author details}

${ }^{1}$ Department of Microbiology, Faculty of Medicine, Medical Microbiology, Hamadan University of Medical Sciences, Hamadan, Iran. ${ }^{2}$ School of Pharmacy, Hamadan University of Medical Sciences, Hamadan, Iran. ${ }^{3}$ Brucellosis Research Center, Hamadan University of Medical Sciences, Hamadan, Iran.

Received: 18 October 2019 Accepted: 9 March 2020

Published online: 19 March 2020

\section{References}

1. Podnos YD, Cinat ME, Wilson SE, Cooke J, Gornick W, Thrupp LD. Eradication of multi-drug resistant Acinetobacter from an intensive care unit. Surg Infect. 2001;2(4):297-301.

2. Baumann P, Doudoroff M, Stanier R. A study of the Moraxella group II. Oxidative-negative species (genus Acinetobacter). J Bacteriol. 1968;95(5): 1520-41.

3. Jung J, Park W. Acinetobacter species as model microorganisms in environmental microbiology: current state and perspectives. Appl Microbiol Biotechnol. 2015;99(6):2533-48.

4. Vaneechoutte M, Dijkshoorn L, Nemec A, Kämpfer P, Wauters G. Acinetobacter, Chryseobacterium, Moraxella, and other nonfermentative Gram-negative rods. In: Versalovic J, editor. Manual of clinical microbiology, vol 1. 10th ed. Washington, DC: ASM Press; 2011. p. 729-31.

5. Manchanda V, Sanchaita S, Singh N. Multidrug resistant acinetobacter. J Global Infect Dis. 2010;2(3):291.

6. Doughari HJ, Ndakidemi PA, Human IS, Benade S. The ecology, biology and pathogenesis of Acinetobacter spp.: an overview. Microbes Environ. 2011; 26(2):101-12.

7. Clinical and Laboratory Standards Institute [CLSI]. Performance Standards for Antimicrobial Susceptibility Testing; Twenty- eight Informational Supplement M100-S28 CLSI. Wayne: CLSI; 2014.

8. Weinstein MP, Limbago B, Patel J, Mathers A, Campeau S, Mazzulli T, et al. M100 performance standards for antimicrobial susceptibility testing. CLSI. 2018.

9. Lin LLB-D, Li X-Z. Distribution of the multidrug efflux pump genes, adeABC, adeDE and adeIJK, and class 1 integron genes in multiple-antimicrobialresistant clinical isolates of Acinetobacter baumannii-Acinetobacter calcoaceticus complex. Int J Antimicrob Agents. 2009;33(1):27-32.

10. Mahmoudi H. Arabestani, M.R., Molavi, M., Karamolah, K.S., Fahim. The study effects antimicrobial of Foeniculum vulgare mill and Achilles mille folium plant on bacterial pathogens causing urinary tract infections and nosocomial infection. Int J Pharmacognosy Phytochem Res. 2016;8(9):154954.

11. Bardbari AM, Arabestani MR, Karami M, Keramat F, Aghazadeh H, Alikhani MY, Bagheri KP. Highly synergistic activity of melittin with imipenem and colistin in biofilm inhibition against multidrug-resistant strong biofilm producer strains of Acinetobacter baumannii. Eur J Clin Microbiol Infect Dis. 2018;37(3):443-54

12. Perez F, Hujer AM, Hujer KM, Decker BK, Rather PN, Bonomo RA. Global challenge of multidrug-resistant Acinetobacter baumannii. Antimicrob Agents Chemother. 2007;51(10):3471-84.

13. Bardbari AM, Arabestani MR, Karami M, Keramat F, Alikhani MY, Bagheri KP. Correlation between ability of biofilm formation with their responsible genes and MDR patterns in clinical and environmental Acinetobacter baumannii isolates. Microb Pathog. 2017;108:122-8. 
14. Ebrahimi M, Khansari-nejad B, Ghaznavi-Rad E. High frequency of ventilator associated pneumonia nosocomial co-infection Causedby methicillin resistant Staphylococcusaureus and Carbapenem resistant Acinetobacter baumannii in intensive care unit. J Clin Res. 2015;1(2):67-71.

15. Saed ABH, Al-Dorzi HM, Khan R, Rishu AH, Arabi YM. Acinetobacter is the most common pathogen associated with late-onset and recurrent ventilator-associated pneumonia in an adult intensive care unit in Saudi Arabia. Int J Infect Dis. 2013;17(9):696-701.

16. Shahcheraghi F, Abbasalipour M, Feizabadi M, Ebrahimipour G, Akbari N Isolation and genetic characterization of metallo- $\beta$-lactamase and carbapenamase producing strains of Acinetobacter baumannii from patients at Tehran hospitals. Iranian J Microbiol. 2011;3(2):68.

17. Ardebili A, Talebi M, Azimi L, Lari AR. Effect of efflux pump inhibitor carbonyl cyanide 3-chlorophenylhydrazone on the minimum inhibitory concentration of ciprofloxacin in Acinetobacter baumannii clinical isolates. Jundishapur J Microbiol. 2014;7(1):e8691.

18. JaponiNejad AR, Sofian M, Ghaznavi-Rad E. Molecular detection of AdeABC efflux pump genes in clinical isolates of Acinetobacter baumannii and their contribution in imipenem resistance. Iran South Med J. 2014;17(5):815-23.

19. Khayat H, Sadeghifard N, Pakzad I, Azimi L, Delfani S, Sayehmiri K, et al. Determination of different fluoroquinolone mechanisms among clinical isolates of acinetobacter baumannii in Tehran. Iran Iranian Red Crescent Medical Journal. 2017;19(9):e58798.

20. Gholami M, Hashemi A, Hakemi-Vala M, Goudarzi H, Hallajzadeh M. Efflux pump inhibitor phenylalanine-arginine B-naphthylamide effect on the minimum inhibitory concentration of imipenem in Acinetobacter baumannii strains isolated from hospitalized patients in Shahid Motahari burn hospital, Tehran, Iran. Jundishapur J Microbiol. 2015;8(10):e19048.

21. Nowak J, Zander E, Stefanik D, Higgins P, Roca I, Vila J, et al. High incidence of pandrug-resistant Acinetobacter baumannii isolates collected from patients with ventilator-associated pneumonia in Greece, Italy and Spain as part of the MagicBullet clinical trial. J Antimicrob Chemother. 2017;72(12): 3277-82.

22. Levy-Blitchtein S, Roca I, Plasencia-Rebata S, Vicente-Taboada W, VelásquezPomar J, Muñoz L, et al. Emergence and spread of carbapenem-resistant Acinetobacter baumannii international clones II and III in Lima, Peru. Emerg Microbes Infect. 2018;7:119.

23. Pourhajibagher M, Hashemi FB, Pourakbari B, Aziemzadeh M, Bahador A. Antimicrobial resistance of Acinetobacter baumannii to imipenem in Iran: a systematic review and meta-analysis. Open Microbiol J. 2016;10:32.

24. Hashemizadeh Z, Bazargani A, Emami A, Rahimi M. Acinetobacter antibiotic resistance and frequency of ESBL-producing strains in ICU patients of Namazi hospital (2008-2009). JQUMS. 2010;14(2):47-53.

25. Coyne S, Courvalin P, Périchon B. Efflux-mediated antibiotic resistance in Acinetobacter spp. Antimicrob Agents Chemother. 2011;55(3):947-53.

26. Coyne S, Guigon G, Courvalin P, Périchon B. Screening and quantification of the expression of antibiotic resistance genes in Acinetobacter baumannii with a microarray. Antimicrob Agents Chemother. 2010;54(1):333-40.

27. Coyne S, Rosenfeld N, Lambert T, Courvalin P, Périchon B. Overexpression of resistance-nodulation-cell division pump AdeFGH confers multidrug resistance in Acinetobacter baumannii. Antimicrob Agents Chemother 2010;54(10):4389-93

28. Rao M, Padyana S, Dipin K, Kumar S, Nayak B. Antimicrobial compounds of plant origin as efflux pump inhibitors: new avenues for controlling multidrug resistant pathogens. J Antimicrob Agents. 2018;4(1000159):247212121000159

29. Gulluce M, Sahin F, Sokmen M, Ozer H, Daferera D, Sokmen A, et al. Antimicrobial and antioxidant properties of the essential oils and methanol extract from Mentha longifolia L. ssp. longifolia. Food Chem. 2007;103(4): 1449-56.

30. Hafedh H, Fethi BA, Mejdi S, Emira N, Amina B. Effect of Mentha longifolia L. ssp longifolia essential oil on the morphology of four pathogenic bacteria visualized by atomic force microscopy. Afr J Microbiol Res. 2010;4(11):1122-7.

31. Saeidi S, Hassanpour K, Ghamgosha M, Heiat M, Taheri RA, Mirhosseini A, et al. Antibacterial activity of ethyl acetate and aqueous extracts of Mentha longifolia L. and hydroalcoholic extract of Zataria multiflora Boiss. Plants against important human pathogens. Asian Pac J Trop Med. 2014;7:S186-S9.

32. Al-Bayati FA. Isolation and identification of antimicrobial compound from Mentha longifolia L. leaves grown wild in Iraq. Ann Clin Microbiol Antimicrobials. 2009;8(1):20.
33. Seasotiya $L$, Dalal $S$. Screening of Indian medicinal plants as efflux pump inhibitors of fluoroquinolones. J Pharmacognosy Phytochem. 2014;3(1):235-41.

34. Roy SK, Kumari N, Pahwa S, Agrahari UC, Bhutani KK, Jachak SM, et al. NorA efflux pump inhibitory activity of coumarins from Mesua ferrea. Fitoterapia. 2013:90:140-50

35. Dwivedi GR, Upadhyay HC, Yadav DK, Singh V, Srivastava SK, Khan F, et al. 4Hydroxy- $a$-Tetralone and its derivative as drug resistance reversal agents in multi drug resistant E scherichia coli. Chem Biol Drug Des. 2014;83(4):482-92.

36. Chitemerere TA, Mukanganyama S. Evaluation of cell membrane integrity as a potential antimicrobial target for plant products. BMC Complement Altern Med. 2014:14(1):278

37. Aghayan SS, Mogadam HK, Fazli M, Darban-Sarokhalil D, Khoramrooz SS, Jabalameli $F$, et al. The effects of berberine and palmatine on efflux pumps inhibition with different gene patterns in Pseudomonas Aeruginosa isolated from burn infections. Avicenna J Med Biotechnol. 2017;9(1):2

38. Smith EC, Williamson EM, Wareham N, Kaatz GW, Gibbons S. Antibacterials and modulators of bacterial resistance from the immature cones of Chamaecyparis lawsoniana. Phytochemistry. 2007;68(2):210-7.

39. Bag A, Chattopadhyay RR. Efflux-pump inhibitory activity of a gallotannin from Terminalia chebula fruit against multidrug-resistant uropathogenic Escherichia coli. Nat Prod Res. 2014;28(16):1280-3.

40. Siriyong $T$, Srimanote $P$, Chusri S, B-e Y, Suaisom C, Tipmanee $V$, et al. Conessine as a novel inhibitor of multidrug efflux pump systems in Pseudomonas aeruginosa. BMC Complementary Alternative Med. 2017;17(1): 405.

41. Cabral V, Luo X, Junqueira E, Costa SS, Mulhovo S, Duarte A, et al. Enhancing activity of antibiotics against Staphylococcus aureus: Zanthoxylum capense constituents and derivatives. Phytomedicine. 2015; 22(4):469-76.

42. Gibbons S, Oluwatuyi M, Kaatz GW. A novel inhibitor of multidrug efflux pumps in Staphylococcus aureus. J Antimicrob Chemother. 2003:51(1):13-7.

\section{Publisher's Note}

Springer Nature remains neutral with regard to jurisdictional claims in published maps and institutional affiliations.

Ready to submit your research? Choose BMC and benefit from:

- fast, convenient online submission

- thorough peer review by experienced researchers in your field

- rapid publication on acceptance

- support for research data, including large and complex data types

- gold Open Access which fosters wider collaboration and increased citations

- maximum visibility for your research: over $100 \mathrm{M}$ website views per year

At $\mathrm{BMC}$, research is always in progress.

Learn more biomedcentral.com/submissions 